\title{
IL-6 Promotes FSH-Induced VEGF Expression Through JAK/STAT3 Signaling Pathway in Bovine Granulosa Cells
}

\author{
Meng Yang Lei Wang Xurong Wang Xuezhi Wang Zhiqiang Yang Jianxi Li \\ Engineering \& Technology Research Center of Traditional Chinese Veterinary Medicine of Gansu \\ Province, Lanzhou Institute of Husbandry and Pharmaceutical Sciences, Chinese Academy of \\ Agricultural Sciences, Lanzhou, China
}

\section{Key words}

Il-6 • VEGF • Granulosa cells • JAK/STAT3 pathway • Angiogenesis

\begin{abstract}
Background/Aims: Vascular endothelial growth factor (VEGF) has been demonstrated to play a pivotal role in the regulation of angiogenesis in ovarian follicular development, particularly during the preovulatory period. Although numerous studies have shown that interleukin- 6 (IL-6) is one of the major inducing factors that regulate the expression of VEGF in non-ovarian cells, whether it involved in regulating the expression of VEGF in normal ovarian granulosa cells is still unknown. The aim of this study was to elucidate the mechanisms underlying the effect of IL- 6 on FSH-induced VEGF expression in bovine granulosa cells derived from large follicles. Methods: VEGF mRNA expression in granulosa cells after IL- 6 with/without inhibitors treatment was analyzed by RT-qPCR. Phosphorylation levels of ERK1/2 and STAT3 proteins induced by IL- 6 were analyzed by western blotting. The protein levels produced by granulosa cells were detected by ELISA. Results: High concentration of IL-6 $(10 \mathrm{ng} / \mathrm{ml})$ can significantly up-regulate FSH-induced VEGF gene and protein expression levels in granulosa cells, and also promote the VEGF upstream regulators HIF- $1 \alpha$ and COX2 mRNA expression. VEGF expression levels were significantly decreased after specifically blocking HIF-1 $\alpha$ and COX2 by using inhibitors. The up-regulation effect of IL- 6 on FSH-induced VEGF expression in granulosa cells mainly through activating the JAK/STAT3 signaling pathway, which can be impaired by JAK inhibitors. Conclusion: IL-6 can promote FSH-induced VEGF expression in granulosa cells, which is mainly achieved by increasing the expression of HIF-1 $\alpha$ and COX2.This promoting effect is mediated by activating the JAK/STAT3 pathway. Moreover, there may be a synergistic relationship between FSH and IL-6 in the regulation of VEGF expression.
\end{abstract}

(C) 2017 The Author(s)

Published by S. Karger AG, Basel 


\section{Cellular Physiology Cell Physiol Biochem 2017;44:293-302 and Biochemistry \begin{tabular}{l|l} 
DOI: 10.1159/000484885 & $\begin{array}{l}\text { Published online: November 13, } 2017 \text { The Author(s). Published by S. Karger AG, Basel } \\
\text { www.karger.com/cpb }\end{array}$
\end{tabular} \\ Yang et al.: IL-6 Promotes FSH-Induced VEGF Expression in Granulosa Cells}

\section{Introduction}

Female fertility depends on the fully development of ovarian follicles until ovulation, which is a continuous process of multi-factor participation. This process is accompanied by a reciprocal cycle of angiogenesis, particularly during the preovulatory period [1]. Newly formed blood vessels can promote the transport of oxygen, nutrients and hormones to the ovaries, and also ensure that different hormones can transfer to target cells [2]. A large number of regulatory factors involved in angiogenesis have been identified and characterized. In particular, vascular endothelial growth factor (VEGF) has been demonstrated to play a pivotal role in the regulation of angiogenesis. VEGF is a specific mitogen for vascular endothelial cells that can directly induce vascular endothelial cell proliferation and formation of blood vessels [3]. In addition to endothelial cells, VEGF gene and protein are also expressed in ovarian granulosa cells, granulosa-lutein cells, thecal cells and thecal-lutein cells [4-6]. It has been found that changes in VEGF expression and its distribution in the ovary are closely related to follicular development and ovulation [7-9].

In addition to regulating the biological function of follicular angiogenesis, VEGF can also increase vascular permeability and promote estrogen and prostaglandin synthesis in ovarian granulosa cells $[1,10]$. It is not only involved in the normal physiological processes of ovarian activity, but also involved in the occurrence and development of many ovulatory disorders [11-13]. Numerous factors have been found to regulate VEGF expression, such as hypoxia-inducible factors, cytokines, growth factors and gonadotropins [1, 11, 14-20]. Although numerous studies have shown that inflammatory cytokines are one of the major inducing factors that regulate the expression of VEGF in non-ovarian cells [21-27], whether inflammatory cytokines are involved in regulating FSH-induced VEGF expression in ovarian follicles are still unknown.

IL-6 produced by a variety of cell types, including ovarian granulosa cells $[28,29]$. IL-6 exerts the biological function by binding to the IL-6 receptor consisting of IL-6R $\alpha$ and a second protein on the cell membrane. IL- 6 first binds to IL-6R $\alpha$, which subsequently associates with a gp130 dimer. The dimerized gp130 triggers activation of the ERK1/2 and JAK/STAT3 signaling pathways [30]. Many studies have found that IL-6 is involved in the angiogenesis process under physiological and pathological conditions, and this effect may be achieved by promoting the expression of VEGF [31, 32]. Therefore, we speculate that IL-6 may also regulate the expression of VEGF in normal granulosa cells. However, IL-6 is a pleiotropic cytokine that exerts different functions in different microenvironments. Moreover, the biological functions of IL-6 in different cells are also different [33]. It remains unclear whether IL-6 can modulate FSH-induced VEGF expression in ovarian granulosa cells.

In the present study, we examined the effects of IL- 6 on FSH-induced VEGF mRNA and protein expression levels and regulatory mechanisms in bovine granulosa cells. The results showed that IL- 6 could promote FSH-induced VEGF expression mRNA and protein expression in granulosa cells, which was mainly achieved by up-regulating HIF- $1 \alpha$ and COX2 expression. In addition, we further found that the JAK/STAT3 signaling pathway participates in this regulatory process.

\section{Materials and Methods}

\section{Antibodies and reagents}

Recombinant bovine IL-6 was purchased from Kingfisher Biotech. U0126, AG490, BAY87-2243, YM155 and NS398 were purchased from Selleck Chemicals. ERK1/2 antibody and phospho-ERK1/2 antibody were purchased from Cell Signaling Technology. Anti-STAT3 antibody and phospho-STAT3 antibody were obtained from LifeSpan BioSciences. $\beta$-actin antibody was purchased from Abcam.

Granulosa cell cultures

Bovine ovaries were collected from a local abattoir and brought to the laboratory within $2 \mathrm{~h}$ after euthanasia. The separation and culture of granulosa cells were carried out according to our previous report 


\section{Cellular Physiology Cell Physiol Biochem 2017;44:293-302 \begin{tabular}{l|l|l}
\hline and Biochemistry 10.1159/000484885 & $\begin{array}{l}\text { C } 2017 \text { The Author(s). Published by S. Karger AG, Basel } \\
\text { www.karger.com/cpb }\end{array}$
\end{tabular}}

Yang et al.: IL-6 Promotes FSH-Induced VEGF Expression in Granulosa Cells

[34]. Briefly, healthy follicles greater from $8 \mathrm{~mm}$ to $17 \mathrm{~mm}$ in diameter were separated after washed with sterile PBS three times. Ovarian follicles were cut in half, and then the follicle walls were washed with serumfree cell culture medium. Granulosa cells were collected by briefly centrifuge and washed three times with the culture medium. The cells were counted and assessed for viability using trypan blue staining. Granulosa cells were cultured in DMEM/F12 (Gibco,USA) supplemented with 1g/L BSA (Sigma,USA), 1\% nonessential amino acids (Gibco,USA), 1\% insulin-transferrin-selenium (Gibco,USA) in a humidified atmosphere under $5 \% \mathrm{CO}_{2}$ at $37^{\circ} \mathrm{C}$.

\section{Extraction of total RNA and preparation of cDNA}

The granulosa cells were cultured in 6-well plates containing $1 \times 10^{6}$ viable cells in $2 \mathrm{ml}$ cell culture medium. Total RNA was extracted from granulosa cells using Trizol reagent (Invitrogen, USA) according to the manufacturer's instructions. cDNA was generated from $1 \mu \mathrm{g}$ of total RNA by using the PrimeScript RT reagent kit (Takara, China). Briefly, $1 \mu \mathrm{g}$ of total RNA was mixed with $2 \mu \mathrm{l}$ of $5 \times \mathrm{g}$ DNA Eraser Buffer, $1 \mu \mathrm{l}$ of gDNA Eraser. RNase Free $\mathrm{dH}_{2} \mathrm{O}$ was complemented to $10 \mu \mathrm{l}$, and then incubated at room temperature for $5 \mathrm{~min}$ to remove genomic DNA. Followed by addition of $10 \mu \mathrm{l}$ of the reverse transcription reaction solution to carry out the reverse transcription reaction and the resulting CDNA was stored at $-20^{\circ} \mathrm{C}$ for subsequent RT-qPCR.

\section{Quantitative real-time PCR}

Quantitative real-time PCR was performed in a total volume of $25 \mu$ l containing $12.5 \mu$ l SYBR premix Ex Taq II, $1 \mu \mathrm{l}$ forward primer $(10 \mu \mathrm{M}), 1 \mu \mathrm{l}$ reverse primer $(10 \mu \mathrm{M})$. The primers involved in the experiment were synthesized by Beijing Genomics Institute. The sequences of all primers used in this work are as follows: IL-6 (forward):5'-ATGCTTCCAATCTGGGTTCAATC-3',IL-6(reverse):5'-ACTCGTTCTGGAGGTAGTCCAGGTA$3^{\prime}$; VEGF (forward): 5' -CCCACGAAGTGGTGAAGTTCA-3', VEGF(reverse): ${ }^{\prime}$-CCACCAGGGTCTCGATGG$3^{\prime}$; HIF-1 $\alpha$ (forward):5'-CCATTTTCCACTCAGGACAC-3',HIF-1 $\alpha$ (reverse):5'-AATTCATCACTGGTGGCTGT$3^{\prime}$; C OX 2 (forward): $5^{\prime}$ - C C T T TAA G G C T TA C C T A C T C A C C A G - $3^{\prime}$, C OX 2 (reverse) : $5^{\prime}$ TGTCAGTGTCAGCACATCCAG-3'; Survivin(forward): $5^{\prime}$-CCTGGCAGCTCTACCTCAAG-3',Survivin(reverse):5'TAAGTAGGCCAACACGAAAG-3';FSHR(forward):5'-AGCCCCTTGTCACAACTCTATGTC-3',FSHR(reverse):5'G T T C C T C ACC G T GAG GTAGAT GT - 3'; GAP D H (forward) : 5' - GAT G G T GAAG G T CG GAGT GAAC $3^{\prime}$,GAPDH(reverse):5'-GTCATTGATGGCGACGATGT-3'. Relative quantifications of mRNA were performed using the $2^{-\Delta \Delta C T}$ comparative method. RNase free $\mathrm{dH}_{2} \mathrm{O}$ was used as the negative control reaction.

\section{SDS/PAGE and western blotting analyses}

Granulosa cells were cultured in $60-\mathrm{mm}$ dishes containing $2.5 \times 10^{6}$ viable cells and incubated with IL-6 and inhibitors when the cells reached subconfluence. The cells were washed with precooled PBS and then lysed with M-PER Mammalian Protein Extraction Reagent (Thermo Scientific). The protein concentrations were determined by the BCA protein assay after the cell lysate centrifugation. The lysate $(20 \mu \mathrm{g})$ was then resolved on $12 \%$ SDS/PAGE gels and electrophoretically transferred to a PVDF membrane. After blocking, the primary antibody was incubated with the protein antigen transferred to the PVDF membrane. After sufficient binding, secondary antibodies were combined with corresponding primary antibody. The immune complexes were visualized by the enhanced chemiluminescence reaction.

\section{Measurement of VEGF production by granulosa cells}

The granulosa cells were cultured in 24-well plates containing $1 \times 10^{5}$ viable cells in $1 \mathrm{ml}$ cell culture medium. The supernatant was collected and centrifuged at $3 \mathrm{~h}$ after the IL-6 and FSH with or without inhibitors treatment. These samples were stored at $-80^{\circ} \mathrm{C}$ until assayed.VEGF secreted by granulosa cells was detected by bovine VEGF ELISA reagent set (GenWay Biotech, USA). Absorbance was measured at $450 \mathrm{~nm}$ using a microplate reader. The concentration of VEGF in the samples was calculated by comparison with the standard curve.

\section{Data analysis}

Data represent means $₫$ SEM from at least three independent experiments. Comparisons between groups were performed by one-way ANOVA. The significance of the differences between the mean values of the control group and each treated group was determined using the Tukey test. A value of $\mathrm{P}<0.05$ was considered significant. 


\section{Cellular Physiology

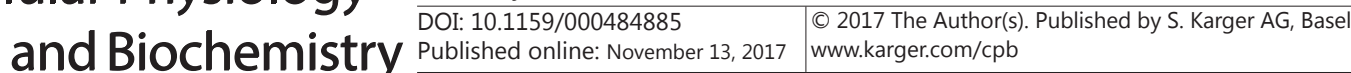 \\ Yang et al.: IL-6 Promotes FSH-Induced VEGF Expression in Granulosa Cells}

\section{Results}

\section{IL-6 promotes FSH-induced VEGF expression in granulosa cells}

Many studies have found that IL-6 can promote VEGF expression in non-granulosa cells and granulosa cell lines. However, whether it regulates VEGF expression in normal granulosa cells is still unknown. Here, we examined the effect of different concentrations of IL-6 (0.1$10 \mathrm{ng} / \mathrm{ml}$ ) on FSH-induced VEGF expression in granulosa cells. The results showed that FSHinduced VEGF mRNA expression levels were significantly increased after treatment with any concentration of IL-6. It was also found that higher concentration of IL-6 (10ng/ml) had a more pronounced effect on FSH-induced VEGF mRNA expression than lower concentration (0.1-3ng/ml) (Fig. 1A). The change trend of VEGF protein production in culture supernatant was consistent with mRNA expression in granulosa cells after IL-6 treatment (Fig. 3A).

In addition, we also analyzed FSH-induced VEGF expression in granulosa cells at different time $(1.5,3,6$ and $12 \mathrm{~h})$ with the same concentration of IL- $6(10 \mathrm{ng} / \mathrm{ml})$ treatment. The results showed that FSH-induced VEGF mRNA expression levels were significantly increased at $1.5 \mathrm{~h}$ and $3 \mathrm{~h}$ after IL-6 treatment compared with the control group (1.5h) (Fig. 1B).

\section{IL-6 promotes FSH-induced HIF-1 $\alpha$ and COX2 mRNA expression in granulosa cells}

Previous studies have shown that HIF- $1 \alpha, \mathrm{COX} 2$ and survivin are important regulators involved in the expression of VEGF. However, little is known about whether these factors are involved in the regulation process of IL- 6 on FSH-induced VEGF expression in granulosa cells. We examined the effect of IL- 6 on FSH-induced HIF- $1 \alpha$, COX2 and survivin mRNA expression in granulosa cells. As shown in Fig. 2A, the FSH-induced HIF-1 $\alpha$ mRNA expression levels were significantly higher than that of the control group after any concentration of IL-6 (0.1-10ng/ $\mathrm{ml}$ ) treatment, while COX2 mRNA expression level was increased only at 1ng/ml (Fig. 2B). Although the expression levels of survivin mRNA was significantly higher from that of the control group after treatment with different concentrations of IL-6, there was no significant difference compared with the FSH treatment alone (Fig. 2C). Thus, IL-6 does not up-regulate FSH-induced survivin mRNA expression in granulosa cells.

HIF-1 $\alpha$ and COX2 are involved in the regulation of IL-6 on FSH-induced VEGF expression in granulosa cells

In order to further demonstrate the important role of HIF- $1 \alpha$ and COX2 in IL- 6 promotes FSH-induced VEGF expression in granulosa cells, we treated cells with HIF-1 $\alpha$, COX2 and Survivin inhibitors to specific blocking HIF- $1 \alpha$, COX2 and survivin, respectively. As shown in
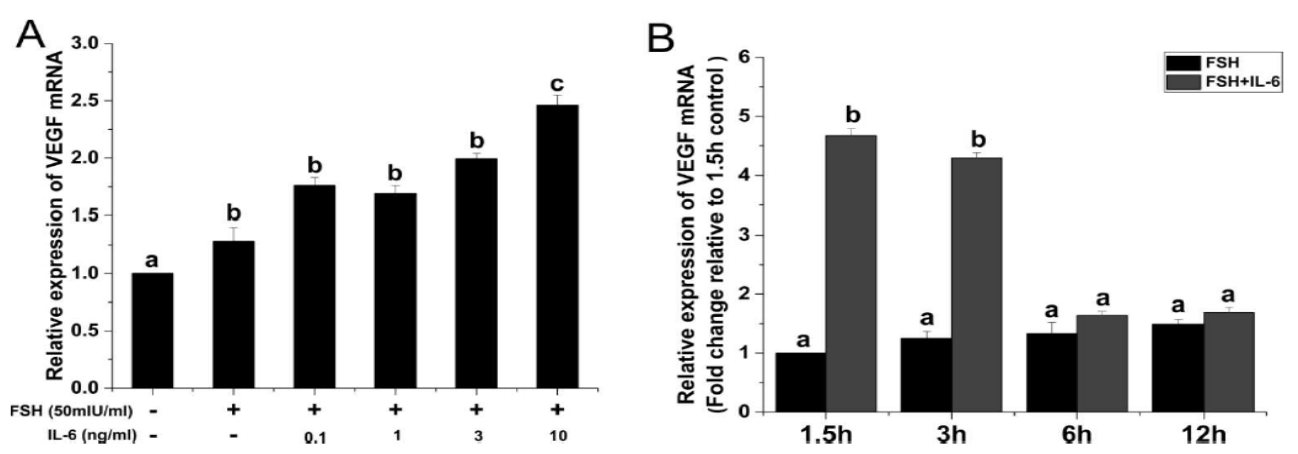

Fig. 1. IL-6 promotes FSH-induced VEGF mRNA expression in granulosa cells.A, Granulosa cells were treated with FSH $(50 \mathrm{mIU} / \mathrm{ml})$ and different concentrations of IL-6(0.1-10ng/ml) for $3 \mathrm{~h}$. The VEGF mRNA expression levels were analyzed using RT-qPCR. B, Granulosa cells were treated with FSH (50mIU/ml) or/ and the same concentration of IL-6 (10ng/ml), and mRNA expression levels were analyzed at 1.5,3,6 and $12 \mathrm{~h}$ using RT-qPCR, respectively. Results were expressed as the mean \pm SEM of at least 3 independent experiments. Values without a common letter were significantly different $(\mathrm{P}<0.05)$. 
Fig. 2D, the expression levels of VEGF mRNA were significantly lower in the HIF- $1 \alpha$ and COX2 inhibitor-treated groups than in the FSH+IL-6 group. However, the expression level of VEGF mRNA was not significantly altered after survivin inhibitor treatment. The change trend of VEGF protein in culture supernatant was consistent with mRNA expression in granulosa cells after inhibitors treatment (Fig. 3B).

Fig. 2. IL-6 promotes FSH-induced HIF-1 $\alpha$ and COX2 mRNA expression in granulosa cells.A, B and C, Granulosa cells were treated with FSH (50mIU/ $\mathrm{ml}$ ) and different concentrations of IL-6(0.1-10ng/ $\mathrm{ml}$ ) for $3 \mathrm{~h}$. The mRNA expression levels of HIF- $1 \alpha$, COX2 and Survivin were analyzed using RT-qPCR, respectively. D, Granulosa cells were pretreated with HIF-1 $\alpha$ inhibitor BAY872243 $(10 \mu \mathrm{M})$, Survivin inhibitor YM155 $(10 \mu \mathrm{M})$ or COX2 inhibitor NS398 $(10 \mu \mathrm{M})$ for $1 \mathrm{~h}$. Cells were then treated with FSH $(50 \mathrm{mIU} / \mathrm{ml})$ and/ or IL-6 $(10 \mathrm{ng} / \mathrm{ml})$ for $3 \mathrm{~h}$. VEGF mRNA levels were measured by RT-qPCR. Re-

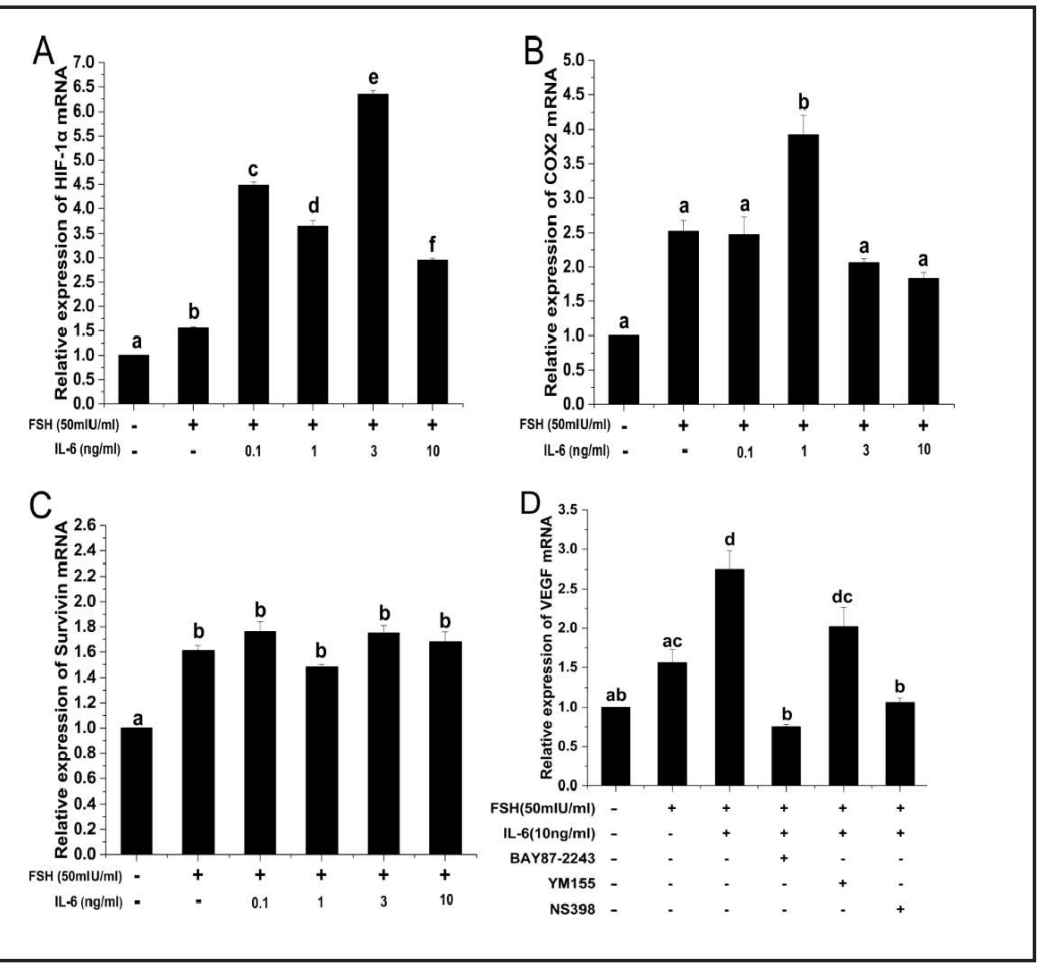
sults were expressed as the mean $\pm \mathrm{SEM}$ of at least 3 independent experiments. Values without a common letter were significantly different $(\mathrm{P}<0.05)$.
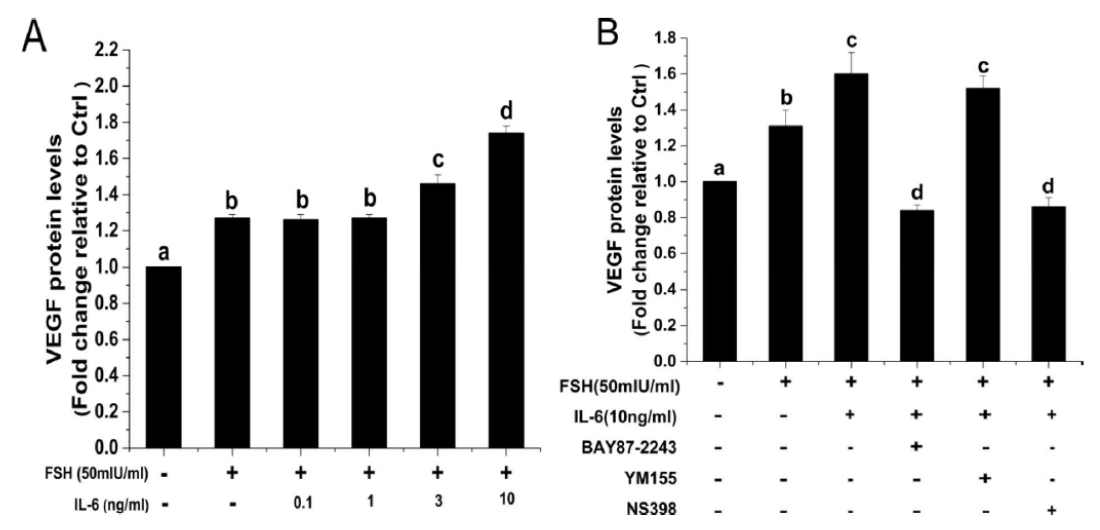

Fig. 3. IL-6 promotes FSH-induced VEGF protein expression levels in granulosa cells.A, Granulosa cells were treated with FSH $(50 \mathrm{mIU} / \mathrm{ml})$ and different concentrations of IL-6 $(0.1-10 \mathrm{ng} / \mathrm{ml})$ for $3 \mathrm{~h}$, and protein expression levels of VEGF were analyzed using ELISA. B, Granulosa cells were pretreated with HIF-1 $\alpha$ inhibitor BAY87-2243(10 $\mu \mathrm{M})$, Survivin inhibitor YM155 $(10 \mu \mathrm{M})$ or COX2 inhibitor NS398 $(10 \mu \mathrm{M})$ for $1 \mathrm{~h}$. Cells were then treated with IL-6 $(10 \mathrm{ng} / \mathrm{ml})$ and FSH $(50 \mathrm{mIU} / \mathrm{ml})$ for $3 \mathrm{~h}$. VEGF protein expression levels were measured by ELISA. Values without a common letter were significantly different $(\mathrm{P}<0.05)$.

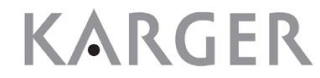


Fig. 4. IL-6 promotes FSHinduced phosphorylation of ERK1/2 and STAT3 proteins in granulose cells.A, The subconfluent granulose cells were exposed to $\mathrm{FSH}(50 \mathrm{mIU} / \mathrm{ml})$ for 5, 15, 30 and $60 \mathrm{~min}$. Wholecell lysates were used for western blotting to detect levels of phosphorylated ERK1/2 (p-ERK1/2) and phosphorylated STAT3 (p-STAT3). B, the granulose cells were exposed to $\mathrm{FSH}(50 \mathrm{mIU} / \mathrm{ml})$ and IL$6(10 \mathrm{ng} / \mathrm{ml})$ for $5,15,30$ and $60 \mathrm{~min}$. Whole-cell lysates were used for western blotting to detect levels of phosphorylated ERK1/2 (p-ERK1/2) and phosphorylated STAT3 (p-STAT3). The detection of ERK1/2 and STAT3 proteins served as a loading control. The phosphorylation level of the protein is expressed as the ratio of the phosphorylated protein to the total protein. Results were ex-
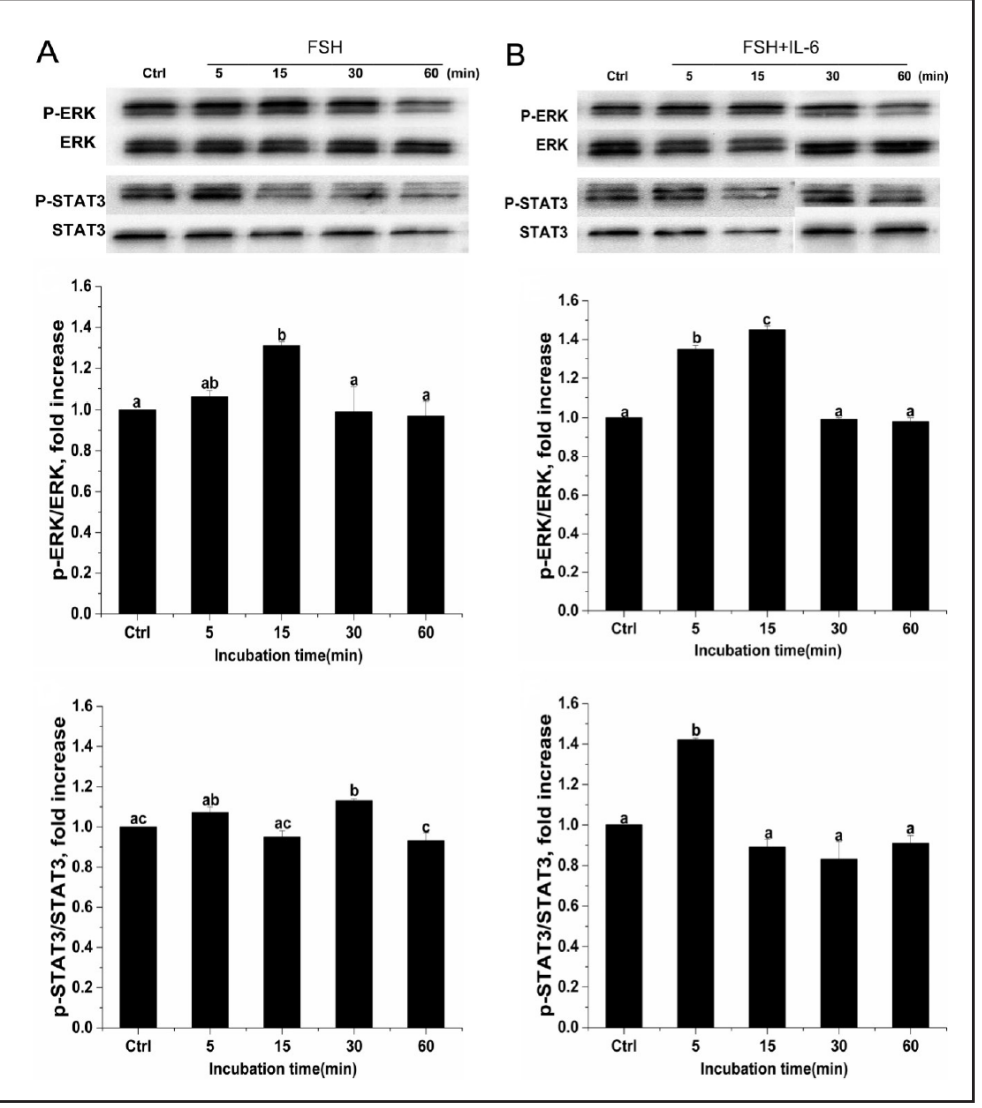
pressed as the mean \pm SEM of at least 3 independent experiments. Values without a common letter were significantly different $(\mathrm{P}<0.05)$.

Fig. 5. JAK inhibitor attenuates the promotive effect of IL-6 on FSH-induced VEGF expression in granulosa cells. Granulosa cells were pretreated with ERK1/2 inhibitor U0126 $(10 \mu \mathrm{M})$ or JAK inhibitor AG490 $(10 \mu \mathrm{M})$ for $1 \mathrm{~h}$ and the cells were then treated with IL-6 $(10 \mathrm{ng} / \mathrm{ml})$ for $3 \mathrm{~h}$. VEGF mRNA levels were measured by RT-qPCR. Results were expressed as the mean \pm SEM of at least 3 independent experiments. Values without a common letter were significantly different $(\mathrm{P}<0.05)$.

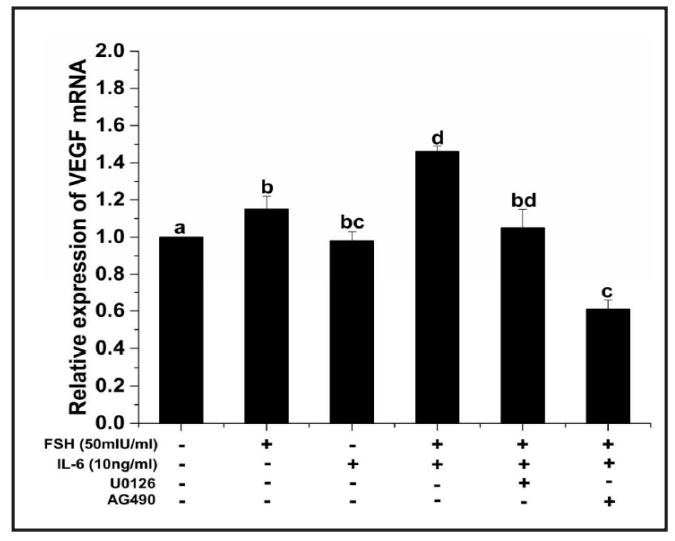

\section{IL-6 promotes phosphorylation of ERK1/2 and STAT3 proteins in granulosa cells}

IL- 6 activates ERK1/2 and JAK/STAT3 signaling pathways by dimerization of gp 130 after binding to IL-6R $\alpha$ on the ovarian granulosa cells membrane. In order to clarify the regulation mechanisms of IL- 6 on VEGF expression in granulosa cells, we used western blotting to detect the phosphorylation levels change of ERK1/2 and STAT3 proteins at different time points (5, 15,30 and $60 \mathrm{~min}$ ) after IL- 6 treatment. The results showed that IL- 6 could promote FSHinduced phosphorylation of ERK1/2 and STAT3 protein in granulosa cells (Fig. 4).

\section{KARGER}



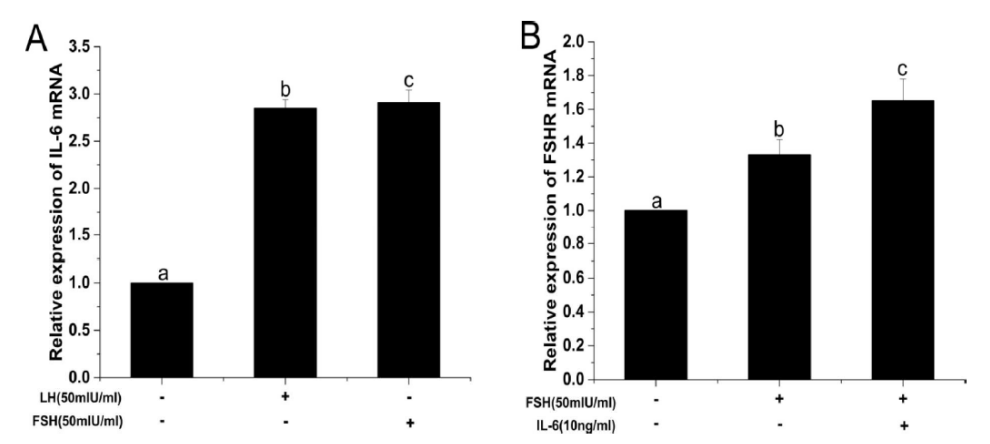

Fig. 6. FSH and LH promote IL-6 mRNA expression in granulosa cells.A, Granulosa cells were treated with FSH $(50 \mathrm{mIU} / \mathrm{ml})$ or LH $(50 \mathrm{mIU} / \mathrm{ml})$ for $3 \mathrm{~h}$. The IL-6 mRNA expression levels were analyzed using RTqPCR. B, Granulosa cells were treated with FSH $(50 \mathrm{mIU} / \mathrm{ml})$ or $/$ and IL-6 $(10 \mathrm{ng} / \mathrm{ml})$ for $24 \mathrm{~h}$, and FSHR mRNA expression levels were analyzed using RT-qPCR. Results were expressed as the mean \pm SEM of at least 3 independent experiments. Values without a common letter were significantly different $(\mathrm{P}<0.05)$.

The regulation of IL-6 on FSH-induced VEGF expression in granulosa cells requires the involvement of JAK/STAT3 signaling pathway

In order to further elucidate the regulatory mechanism of IL-6 on FSH-induced VEGF expression in granulosa cells, we used ERK1/2 and JAK inhibitors to specifically block the corresponding signaling pathways. As shown in Fig. 5, the expression levels of VEGF mRNA in AG490 (JAK inhibitors) group was significantly lower than that in control group (FSH+IL-6 group). However, the expression of VEGF mRNA was not significantly changed after U0126 (ERK1/2 inhibitors) treatment.

\section{Gonadotropin promotes IL-6 mRNA expression in granulosa cells}

There are complex interrelationships between steroid hormones, cytokines, growth factors and gonadotropin-derived gonadotropins in the local follicles during follicular development and ovulation. In order to clarify the interaction between FSH and IL-6 in regulating the expression of VEGF in granulosa cells, we investigate the effect of gonadotropin on the expression of IL-6 in granulosa cells. As shown in Fig. 6A, Gonadotropin, including FSH and LH, can promote the expression of IL- 6 mRNA, whereas IL- 6 can also increase the expression of FSHR mRNA in granulosa cells (Fig. 6B).

\section{Discussion}

In this study, we found that IL-6 can promote the FSH-induced VEGF expression in bovine granulosa cells, which is mainly achieved by increasing the expression of HIF$1 \alpha$ and COX2. VEGF mRNA and protein expression levels were significantly reduced after specifically blocking HIF- $1 \alpha$ and COX2 expression by inhibitors. We further found that JAK/ STAT3 signaling pathway involved in the regulation of IL-6 on FSH-induced VEGF expression in granulosa cells.

VEGF is not only involved in the occurrence and development of many ovarian diseases, but also plays an important role in the physiological processes, such as follicular development, ovulation and corpus luteum formation [1,2]. Although a large number of studies have confirmed that inflammatory cytokines play a pivotal role in these biological events in follicular development and ovulation, IL-6 as a major type of inflammatory cytokine, whether it is involved in the regulation of VEGF expression in granulosa cells is unclear. Here, we investigated the regulatory role of IL- 6 on FSH-induced VEGF expression in normal granulosa cells. We found that high concentrations of IL- 6 can promote FSH-induced VEGF mRNA and protein expression. This is consistent with the results of the study on granulosa 


\section{Cellular Physiology Cell Physiol Biochem 2017;44:293-302 \begin{tabular}{l|l|l} 
and BOI: 10.1159/000484885 & $\begin{array}{l}\text { (c) 2017 The Author(s). Published by S. Karger AG, Basel } \\
\text { www.karger.com/cpb }\end{array}$
\end{tabular}}

Yang et al.: IL-6 Promotes FSH-Induced VEGF Expression in Granulosa Cells

cell lines [11]. Together with previous studies, IL-6 and FSH may have synergistic effect in regulating VEGF expression. In order to further clarify this synergistic effect, we investigated the IL- 6 and FSH receptor expression in granulosa cells derived from large follicles after treatment with gonadotropin and IL-6, respectively. The results show that FSH can promote the expression of IL-6 mRNA, whereas IL-6 can also increase the expression of FSHR mRNA in granulosa cells. This result demonstrates that it is possible to amplify the regulatory effect of FSH or IL- 6 on cells after IL- 6 combined with FSH treatment. It also suggests that IL-6 not only regulates VEGF expression under pathological conditions, but also plays an important regulatory role in physiological conditions.

The expression of VEGF is regulated by a variety of factors. HIF- $1 \alpha$ is a key promoter of VEGF expression in pathological conditions [35-37]. Our study shows that IL-6 can significantly increase the FSH-induced HIF- $1 \alpha$ expression level in normal granulosa cells. In addition, we also found that IL- 6 can also promote the FSH-induced COX2 expression level, which is another important gene that regulates VEGF expression in the follicular development and ovulation. It can be speculated that the regulatory effect of IL- 6 on FSHinduced VEGF expression may be achieved by inducing the expression of HIF- $1 \alpha$ and COX2. In order to confirm this inference, we used BAY87-2243 (HIF-1 $\alpha$ inhibitor) and NS398 (COX2 inhibitor) to specifically block HIF- $1 \alpha$ and COX2, and found that IL- 6 promotes FSH-induced VEGF mRNA expression was significantly decreased. Taken together, the above studies have shown that IL-6 mainly promotes FSH-induced VEGF expression in granulosa cells by inducing the expression of HIF- $1 \alpha$ and COX2.

For granulosa cells, IL- 6 regulates the expression of target genes by binding to IL- 6 receptors and initiating ERK1/2 and JAK/STAT3 signaling pathways. In order to elucidate the regulatory mechanism of IL-6 promotes FSH-induced VEGF expression in granulosa cells, we used inhibitors to specifically block the corresponding signaling pathway. The results show that FSH-induced VEGF mRNA expression levels were decreased significantly after AG490 (JAK inhibitor) treatment. However, the expression of VEGF mRNA was not significantly changed after U0126 (ERK1/2 inhibitors) treatment. In addition, we also used western blotting to detect changes in intracellular phosphorylation levels after IL-6 treatment. The results showed that IL-6 can significantly increase FSH-induced phosphorylation levels ERK1/2 and STAT3 proteins in granulosa cells. The results once again demonstrated the synergistic effect between IL-6 and FSH in regulating VEGF expression. All of the above studies have shown that JAK/STAT3 signaling pathway is involved in the regulation of VEGF expression in granulosa cells. This is consistent with the results of the study in the granulosa cell lines $[11,37]$. In addition to the ERK1/2 pathway, many studies have shown that the JAK/STAT3 pathway plays a key role in different induction factors. Moreover, the biological functions of granulosa cells will be inhibited after specific blocking of the JAK/STAT3 signaling pathway. Our study combined in previous studies shows that JAK/STAT3 pathway plays an important role in regulating follicular development and ovulation, including promoting VEGF gene expression.

Numerous studies have confirmed that inflammatory cytokines play an important regulatory role in ovarian activity [38-40]. In particular, the discovery and application of specific inhibitors and gene knockout animals have more substantiated the previous speculation about the involvement of inflammatory cytokines in follicular development and ovulation. However, the previous and our present study mainly focused on a single type of inflammatory cytokines. The study still lacks the role of cytokine network in ovarian cycle. At present, the biological effects of cytokines in regulating follicular development and ovulation have been recognized, but the mechanisms of the overall regulatory effect in the ovarian cycle remains to be studied.

\section{Conclusion}

Our study confirms that IL-6 can promote FSH-induced VEGF synthesis in bovine granulosa cells by increasing the expression of HIF- $1 \alpha$ and COX2. The up-regulation effect 


\section{Cellular Physiology Cell Physiol Biochem 2017;44:293-302 \begin{tabular}{l|l|l} 
and Biochemistry Published online: November 13, 2017 & $\begin{array}{l}\text { (c) } 2017 \text { The Author(s). Published by S. Karger AG, Basel } \\
\text { www.karger.com/cpb }\end{array}$
\end{tabular}}

Yang et al.: IL-6 Promotes FSH-Induced VEGF Expression in Granulosa Cells

of IL-6 on FSH-induced VEGF expression in bovine granulosa cells mainly through activating the JAK/STAT3 signaling pathway. It is not only conducive to clarify the intrinsic mechanism of IL-6 in regulating ovarian activities, but also help to elucidate the possible mechanism of the occurrence of ovulatory disorders.

\section{Acknowledgements}

This work was supported by the Dairy Industry Technology and Systems Projects (CARS37), Agro-scientific Research in the Public Interest (201303040-01) and Chinese Central Government for Basic Scientific Research Operations in Commonweal Research Institutes (1610322014004).

\section{Disclosure Statement}

All authors declare that they have no Disclosure Statement.

\section{References}

1 Geva E, Jaffe RB: Role of vascular endothelial growth factor in ovarian physiology and pathology. Fertil Steril 2000;74:429-438.

2 Kaczmarek MM, Schams D, Ziecik AJ: Role of vascular endothelial growth factor in ovarian physiology-an overview. Reprod Biol 2005;5:111-136.

3 Ferrara N, Davis-Smyth T: The biology of vascular endothelial growth factor. Endocr Rev 1997;18:4-25.

4 Kamat BR, Brown LF, Manseau EJ, Senger DR, Dvorak HF: Expression of vascular permeability factor/ vascular endothelial growth factor by human granulosa and theca lutein cells. Role in corpus luteum development. Am J Pathol 1995;146:157-165.

-5 Yamamoto S, Konishi I, Tsuruta Y, Nanbu K, Mandai M, Kuroda H, Matsushita K, Hamid AA, Yura Y, Mori T: Expression of vascular endothelial growth factor (VEGF) during folliculogenesis and corpus luteum formation in the human ovary. Gynecol Endocrinol 1997;11:371-381.

6 Yan Z, Weich HA, Bernart W, Breckwoldt M, Neulen J: Vascular endothelial growth factor (VEGF) messenger ribonucleic acid (mRNA) expression in luteinized human granulosa cells in vitro. J Clin Endocrinol Metab 1993;77:1723-1725.

7 Neulen J, Yan Z, Raczek S, Weindel K, Keck C, Weich HA, Marmé D, Breckwoldt M: Human chorionic gonadotropin-dependent expression of vascular endothelial growth factor/vascular permeability factor in human granulosa cells: importance in ovarian hyperstimulation syndrome. J Clin Endocrinol Metab 1995;80:1967-1971.

8 Hazzard T, Molskness T, Chaffin C, Stouffer R: Vascular endothelial growth factor (VEGF) and angiopoietin regulation by gonadotrophin and steroids in macaque granulosa cells during the peri-ovulatory interval. Mol Hum Reprod 1999;5:1115-1121.

-9 Nishigaki A, Okada H, Okamoto R, Sugiyama S, Miyazaki K, Yasuda K, Kanzaki H: Concentrations of stromal cell-derived factor-1 and vascular endothelial growth factor in relation to the diameter of human follicles. Fertil Steril 2011;95:742-746.

10 Grasselli F, Basini G, Bussolati S, Tamanini C: Effects of VEGF and bFGF on Proliferation and Production of Steroids and Nitric Oxide in Porcine Granulosa Cells. Reprod Domest Anim 2002;37:362-368.

11 Yan H, Hua K, Zhou X, Jin H, Chen X, Xin L, Yu Y, Zha X, Feng Y: Activation of the PI3K/AKT pathway mediates FSH-stimulated VEGF expression in ovarian serous cystadenocarcinoma. Cell Res 2008;18:780-791.

12 Agrawal R, Jacobs H, Payne N, Conway G: Concentration of vascular endothelial growth factor released by cultured human luteinized granulosa cells is higher in women with polycystic ovaries than in women with normal ovaries. Fertil Steril 2002;78:1164-1169.

13 Ebisch IMW, Thomas CMG, Wetzels AMM, Willemsen WNP, Sweep FCGJ, Steegers-Theunissen RPM: Review of the role of the plasminogen activator system and vascular endothelial growth factor in subfertility. Fertil Steril 2008;90:2340-2350.

14 Fang J, Xia C, Cao Z, Zheng JZ, Reed E, Jiang BH: Apigenin inhibits VEGF and HIF-1 expression via PI3K/AKT/ p70S6K1 and HDM2/p53 pathways. FASEB J 2005;19:342-353.

15 Zhong XS, Zheng JZ, Reed E, Jiang BH: SU5416 inhibited VEGF and HIF-1 $\alpha$ expression through the PI3K/ AKT/p70S6K1 signaling pathway. Biochem Biophys Res Commun 2004;324:471-480. 


\section{Cellular Physiology Cell Physiol Biochem 2017;44:293-302 \begin{tabular}{l|l} 
and Biochemistry Published online: November 13, 2017 & $\begin{array}{l}\text { (c) } 2017 \text { The Author(s). Published by S. Karger AG, Basel } \\
\text { www.karger.com/cpb }\end{array}$
\end{tabular}}

Yang et al.: IL-6 Promotes FSH-Induced VEGF Expression in Granulosa Cells

16 Einspanier R, Schönfelder M, Müller K, Stojkovic M, Kosmann M, Wolf E, Schams D: Expression of the vascular endothelial growth factor and its receptors and effects of VEGF during in vitro maturation of bovine cumulus-oocyte complexes (COC). Mol Reprod Dev 2002;62:29-36.

$>17$ Wang J, Luo F, Lu JJ, Chen PK, Liu P, Zheng W: VEGF expression and enhanced production by gonadotropins in ovarian epithelial tumors. Int J Cancer 2002;97:163-167.

18 Fátima LA, Evangelista MC, Silva RS, Cardoso APM, Baruselli PS, Papa PC: FSH up-regulates angiogenic factors in luteal cells of buffaloes. Domest Anim Endocrinol 2013;45:224-237.

19 Ferrari B, Pezzuto A, Barusi L, Coppola F: Follicular fluid vascular endothelial growth factor concentrations are increased during GnRH antagonist/FSH ovarian stimulation cycles. Eur J Obstet Gynecol 2006;124:7076.

20 Shin SY, Lee HJ, Ko DS, Lee HC, Park WI: The regulators of VEGF expression in mouse ovaries. Yonsei Med J 2005;46:679-686.

21 Honorati MC, Cattini L, Facchini A: IL-17, IL-1 $\beta$ and TNF- $\alpha$ stimulate VEGF production by dedifferentiated chondrocytes. Osteoarthritis Cartilage 2004;12:683-691.

22 Theoharides TC, Zhang B, Kempuraj D, Tagen M, Vasiadi M, Angelidou A, Kalogeromitros D, Asadi S, Stavrianeas N: IL-33 augments substance P-induced VEGF secretion from human mast cells and is increased in psoriatic skin. Proc Natl Acad Sci U S A 2010;107:4448-4453.

23 Jung YJ, Isaacs JS, Lee S, Trepel J, Neckers L: IL-1beta-mediated up-regulation of HIF-1alpha via an NFkappa B/COX-2 pathway identifies HIF-1 as a critical link between inflammation and oncogenesis. FASEB J 2003;17:2115-2117.

-24 Tanaka T, Kanai H, Sekiguchi K, Aihara Y, Yokoyama T, Arai M, Kanda T, Nagai R, Kurabayashi M: Induction of VEGF Gene Transcription by IL-1 $\beta$ is Mediated Through Stress-activated MAP Kinases and Sp1 Sites in Cardiac Myocytes. J Mol Cell Cardiol 2000;32:1955.

25 Dias S, Boyd R, Balkwill F: IL - 12 regulates VEGF and MMPs in a murine breast cancer model. Int J Cancer 1998;78:361.

26 Liu J, Duan Y, Cheng X, Chen X, Xie W, Long H, Lin Z, Zhu B: IL-17 is associated with poor prognosis and promotes angiogenesis via stimulating VEGF production of cancer cells in colorectal carcinoma. Biochem Biophys Res Commun 2011;407:348-354.

27 Jiang S, Li Y, Lin T, Yuan L, Li Y, Wu S, Xia L, Shen H, Lu J: IL-35 Inhibits Angiogenesis through VEGF/Ang2/ Tie2 Pathway in Rheumatoid Arthritis. Cell Physiol Biochem 2016;40:1105-1116.

28 Machelon V, Emilie D, Lefevre A, Nome F, Durand-Gasselin I, Testart J: Interleukin-6 biosynthesis in human preovulatory follicles: some of its potential roles at ovulation. J Clin Endocrinol Metab 1994;79:633-642.

29 Gorospe WC, Jr HF, Spangelo BL: Interleukin-6: effects on and production by rat granulosa cells in vitro. Endocrinology 1992;130:1750-1752.

30 Hunter CA, Jones SA: IL-6 as a keystone cytokine in health and disease. Nat Immunol 2015;16:448-457.

-31 Motro B, Itin A, Sachs L, Keshet E: Pattern of interleukin 6 gene expression in vivo suggests a role for this cytokine in angiogenesis. Proc Natl Acad Sci U S A 1990;87:3092-3096.

>32 Gertz K, Kronenberg G, Kälin RE, Baldinger T, Werner C, Balkaya M, Eom GD, Hellmann-Regen J, Kröber J, Miller KR: Essential role of interleukin-6 in post-stroke angiogenesis. Brain 2012;135:1964-1980.

33 Rincon M: Interleukin-6: from an inflammatory marker to a target for inflammatory diseases. Trends Immunol 2012;33:571-577.

34 Yang M, Wang X, Wang L, Wang X, Yang Z, Li J: IL-1 $\alpha$ Up-Regulates IL-6 Expression in Bovine Granulosa Cells via MAPKs and NF- $\kappa B$ Signaling Pathways. Cell Physiol Biochem 2017;41:265-273.

-35 Jung JE, Lee HG, Cho IH, Chung DH, Yoon SH, Yang YM, Lee JW, Choi S, Park JW, Ye SK: STAT3 is a potential modulator of HIF-1-mediated VEGF expression in human renal carcinoma cells. FASEB J 2005;19:1296.

-36 Komatsu DE, Hadjiargyrou M: Activation of the transcription factor HIF-1 and its target genes, VEGF, HO-1, iNOS, during fracture repair. Bone 2004;34:680-688.

37 Horiuchi A, Imai T, Shimizu M, Oka K, Wang C, Nikaido T, Konishi I: Hypoxia-induced changes in the expression of VEGF, HIF-1 alpha and cell cycle-related molecules in ovarian cancer cells. Anticancer Res 2002;22:2697-2702.

-38 Salmassi A, Lü S, Hedderich J, Oettinghaus C, Jonat W, Mettler L: Interaction of interleukin-6 on human granulosa cell steroid secretion. J Endocrinol 2001;170:471-478.

39 Smith MP, Flannery GR, Randle BJ, Jenkins JM, Holmes CH: Leukocyte origin and profile in follicular aspirates at oocyte retrieval. Hum Reprod 2005;20:3526-3531.

-40 Field SL, Dasgupta T, Cummings M, Orsi NM: Cytokines in ovarian folliculogenesis, oocyte maturation and luteinisation. Mol Reprod Dev 2014;81:284-314. 